\title{
Radon Concentration in Soil and Radon Exhalation Rate at Al-Dora Refinery and Surrounding Area in Baghdad
}

\author{
Nada F. Tawfiq, Jaafar Jaleel \\ Physics Department, College of Science, Al-Nahrain University, Baghdad, Iraq \\ Email: nadafathil@yahoo.com
}

Received 4 August 2015; accepted 15 September 2015; published 18 September 2015

Copyright (C) 2015 by authors and Scientific Research Publishing Inc.

This work is licensed under the Creative Commons Attribution International License (CC BY). http://creativecommons.org/licenses/by/4.0/

(c) $\underset{\mathrm{EY}}{0}$ Open Access

\begin{abstract}
Radongas concentrations in soil samples were determined from depths (surface, 15, and 30 ) $\mathbf{c m}$ for nine locations in Al-Dora refinery and surrounding area using "sealed can technique" and CR39 solid state nuclear track detectors. The radon concentration in surface samples ranged from 810.08 to $1380.08 \mathrm{~Bq} / \mathrm{m}^{3}$ with an average $1137.71 \mathrm{~Bq} / \mathrm{m}^{3}$. The radon concentration in soil at the depth $15 \mathrm{~cm}$ was ranged from 490.5 to $1197.52 \mathrm{~Bq} / \mathrm{m}^{3}$ with an average $732.78 \mathrm{~Bq} / \mathrm{m}^{3}$ and at the depth $30 \mathrm{~cm}$ was ranged from 362.07 to $889.53 \mathrm{~Bq} / \mathrm{m}^{3}$ with an average $529.41 \mathrm{~Bq} / \mathrm{m}^{3}$. The surface exhalation rate in surface soil samples ranged was 0.44 , to $0.99 \mathrm{~Bq} \cdot \mathrm{m}^{-2} \cdot \mathrm{h}^{-1}$ with average 0.61 $\mathrm{Bq} \cdot \mathrm{m}^{-2} \cdot \mathrm{h}^{-1}$. The surface exhalation rate in soil samples at the depth $15 \mathrm{~cm}$ was ranged from 0.22 to $0.64 \mathrm{~Bq} \cdot \mathrm{m}^{-2} \cdot \mathrm{h}^{-1}$ with average $0.39 \mathrm{~Bq} \cdot \mathrm{m}^{-2} \cdot \mathrm{h}^{-1}$. The surface exhalation rate in soil samples at the depth $15 \mathrm{~cm}$ was ranged from 0.22 to $0.64 \mathrm{~Bq} \cdot \mathrm{m}^{-2} \cdot \mathrm{h}^{-1}$ with average $0.39 \mathrm{~Bq} \cdot \mathrm{m}^{-2} \cdot \mathrm{h}^{-1}$. The surface exhalation rate and the mass exhalation rate in soil samples at the depth $30 \mathrm{~cm}$ ranged from 0.19 , to $0.48 \mathrm{~Bq} \cdot \mathrm{m}^{-2} \cdot \mathrm{h}^{-1}$ with average $0.28 \mathrm{~Bq} \cdot \mathrm{m}^{-2} \cdot \mathrm{h}^{-1}$. The mass exhalation rate in surface soil samples ranged from 0.09 to $0.21 \mathrm{~Bq} \cdot \mathrm{kg}^{-1} \cdot \mathrm{h}^{-1}$ with average $0.12 \mathrm{~Bq} \cdot \mathrm{kg}^{-1} \cdot \mathrm{h}^{-1}$. The mass exhalation rate in soil samples from depth $15 \mathrm{~cm}$ was ranged from 0.046 to $0.14 \mathrm{~Bq} \cdot \mathrm{kg}^{-1} \cdot \mathrm{h}^{-1}$ with average 0.08 $\mathrm{Bq} \cdot \mathrm{kg}^{-1} \cdot \mathrm{h}^{-1}$. The mass exhalation rate in soil samples at the depth $30 \mathrm{~cm}$ was ranged from 0.042 to $0.1 \mathrm{~Bq} \cdot \mathrm{kg}^{-1} \cdot \mathrm{h}^{-1}$ with average $0.06 \mathrm{~Bq} \cdot \mathrm{kg}^{-1} \cdot \mathrm{h}^{-1}$.
\end{abstract}

\section{Keywords}

Radon Concentration, Soil Sample, CR-39 Track Detector, Radon Exhalation Rate

\section{Introduction}

The knowledge on radioactivity contents of the various radio-nuclides in soil and rocks plays an important role 
in health physics. The naturally occurring radionuclides ${ }^{226} \mathrm{Ra},{ }^{232} \mathrm{Th}$ and ${ }^{40} \mathrm{~K}$ are the main sources of radiation in soils and rocks.

The gaseous radioactive radon $\left({ }^{222} \mathrm{Rn}\right)$, decay product of the radium isotope ${ }^{226} \mathrm{Ra}$ is present in all types of soil and rock. Radium atoms decays in soil particles, the resulting atoms of radon entering to air filled pores and then transported by diffusion and advection through this space in order to exhale into the atmosphere [1].

The half-life of ${ }^{222} \mathrm{Rn} 3.8$ days is long enough for part of it to diffuse from the indoor radon sources to the inside of the room. Therefore ${ }^{222} \mathrm{Rn}$ is the most dominant hazardous radionuclide among the radon isotopes. Both radon and its progeny attached to aerosols are present in the ambient air. ${ }^{222} \mathrm{Rn}$ gas can enter the house from the soil. When it penetrates into closed rooms and become concentrated, it sometimes reaches harmful levels for public health [2].

So the radon from soil gas is the main cause of radon problem. Based on the National Academy of Science 1998 BEIR VI Report, the US Environmental Protection Agency estimates that about 21,000 annual lung cancer deaths are radon related. EPA also concluded that the effects of radon and cigarette smoking are synergistic, so that smokers are at higher risk from radon, from which it can be concluded that radon is the second leading cause of lung cancer after smoking [3]. The factors which influence the diffusion of radon from the soil into the air are: 1) The uranium and radium concentration in soil and rocks; 2) The emanation capacity of the ground; 3) The porosity of the rock and soil; Barometric pressure gradient between the interfaces; 4) Soil moisture and water saturation grade of the medium; 5) Other variables [4].

The radon and its progeny enter into human's body mainly through ingestion and inhalation [5]. Exposure of person to high concentration of radon and its short-lived progeny for a long period leads to health problems, particularly lung cancer [6].

The determination of radon entry rates into pore spaces, also called emanation rate, and its exhalation to the atmosphere depends on the radon concentrations in soil, on the distribution and concentrations of the radium radionuclide in the bedrock and on the permeability of the soil as well [4].

Although geological substrates potentially fertile to the release of radon should have a basic feature, enriched in uranium and thorium and fractured, these are not, however, enough conditions, especially in areas with hot and humid climate, where important bio genetics residuals cover the rocks. Other crucial properties of the ground for secondary porosity are: type and thickness of soils and their distribution space, water regime and geometry of the aquifer table. In this context, rocks with the same levels in normal radionuclide uranium and thorium can be transformed into an appreciable radon supplier's material [7].

Radon exhalation from soil depends not only on the radium concentration, but also on factors such as:

- The fraction of radon produced which is released from the soil's grain to its interstitial space, also known as the emanation power of fraction;

- The porosity of the material;

- The surface preparation and soil covering [8].

Thus, this paper aims is to measure radon concentration, surface exhalation rate and mass exhalation rate in Al-Dora refinery and surrounding area soil samples to know about the existence of high levels of radon gas.

\section{Materials and Methods}

\subsection{Measurement of Radon Gas Concentrations}

The radon and its daughters were detected by using CR-39 nuclear track detector of thickness $(250 \mu \mathrm{m})$ and "sealed can technique" [9].

AL-Dora refinery is located in Baghdad-Iraq. A total of 27 soil samples were collected from Al-Dora refinery and surrounding area from surface, $15 \mathrm{~cm}$ and $30 \mathrm{~cm}$ depth as shown in Table 1 . The dust samples were collected from five locations around Al-Dora refinery. These samples were crushed to fine powder by using electrical mill, the fine soil powder will convert to the grain size of $(300 \mu \mathrm{m}),(5 \mathrm{~g})$ of each sample which was placed inside a plastic cylindrical container facingCR-39 track detector into a diffusion chamber Figure 1.

The container was then sealed for two months; during that time, $\alpha$ particles emitted by radon and their daughters bombarded the CR-39 track detectors. After the irradiation, the detectors were developed in $\mathrm{NaOH}$ solution $6.25 \mathrm{~N}$ at $60^{\circ} \mathrm{C}$ for 6 hours; after chemical etching, $\alpha$ particle track densities were determined by an optical microscope $400 \times$. The radon concentration $C_{\mathrm{Rn}}$ in $\mathrm{Bq} / \mathrm{m}^{3}$ was determined by the following equation: 
Table 1. Soil samples locations.

\begin{tabular}{cc}
\hline Locations & Symbols \\
\hline Baghdad AL-Jadida & S1 \\
Dora refinery near crude oil tanks & S2 \\
Dora refinery near diesel tanks & S3 \\
Dora refinery near white oil tanks & S4 \\
Dora refinery (garden) & S5 \\
Dora refinery near oil pipes & S6 \\
Dora & S7 \\
Karada & S8 \\
Zafraniya & S9 \\
\hline
\end{tabular}

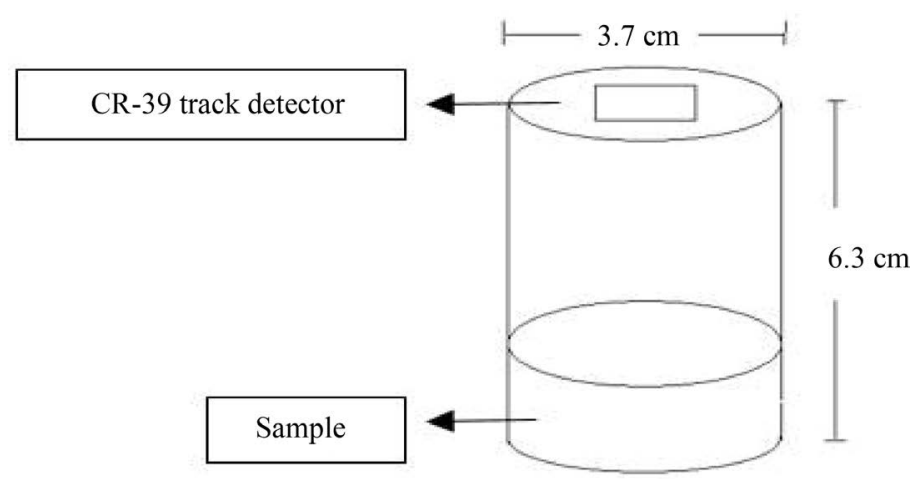

Figure 1. The apparatus used to study the radon concentration of soil samples.

$$
C_{\mathrm{Rn}}=\frac{\rho_{x}}{K T}
$$

where $\rho_{x}$ is the track density in (tracks $\cdot \mathrm{mm}^{-2}$ ), $T$ is the exposure time in (days) and $K$ is the calibration factor of $\left(0.42 \pm 0.02\left(\right.\right.$ tracks $\left.\left.\cdot \mathrm{mm}^{-2}\right) \mathrm{Bq}^{-1} \cdot \mathrm{m}^{-1} \mathrm{~h}^{-1}\right)$ (Figure 2).

\subsection{Calculation of Radon Exhalation Rate in Soil Samples}

The radon exhalation rate in terms of area $E_{x}$ in $\left(\mathrm{Bq} \cdot \mathrm{m}^{-2} \cdot \mathrm{h}^{-1}\right)$ was calculated as follows [10] [11]:

$$
E_{x}=\frac{C V \lambda}{A\left[T+\lambda^{-1}\left(\mathrm{e}^{-\lambda T}-1\right)\right]}
$$

where $C$ is the integrated radon exposure measured by the CR-39 SSNTD

$\left(\mathrm{Bq} \cdot \mathrm{m}^{-3} \cdot \mathrm{h}\right), V$ is the effective volume of the container $\left(\mathrm{m}^{3}\right), \lambda$ is the decay constant of radon $\left(\mathrm{h}^{-1}\right)$, $\mathrm{T}$ is the exposition time $(\mathrm{h})$, and $\mathrm{A}$ is the area covered by the container $\left(\mathrm{m}^{2}\right)$.

The radon exhalation rate in terms of mass $E_{m}$ in $\left(\mathrm{Bq} \cdot \mathrm{kg}^{-1} \cdot \mathrm{h}^{-1}\right)$ was calculated as:

$$
E_{m}=\frac{C V \lambda}{M\left[T+\lambda^{-1}\left(\mathrm{e}^{-\lambda T}-1\right)\right]}
$$

where $M$ is the mass of the sample $(\mathrm{kg})$.

\section{Results and Discussion}

In the present work Radon concentrations were measured for soil samples (surface and from depth 15, $30 \mathrm{~cm}$ ) in 
9 different locations in Al-Dora refinery and surrounding. The dust samples were collected from five locations around Al-Dora refinery Table 1 . These regions were chose to measure the natural occurring radioactive material which comes from Al-Dora refinery at this region.

Tables 2-4 and Figures 3-5 summarize the results obtained in the present work for radon gas concentrations, the surface exhalation rate and the mass exhalation rate in (surface, 15, $30 \mathrm{~cm}$ depth) soil samples.

It can be noticed that the radon concentration values in surface samples were at the range from 810.08 to $1380.08 \mathrm{~Bq} / \mathrm{m}^{3}$ with an average $1137.71 \mathrm{~Bq} / \mathrm{m}^{3}$. The highest value was in Dora refinery near white oil tanks and the lowest in AL-Karada region as shown in Figure 3.

The radon concentrations in soil from depth $15 \mathrm{~cm}$ were at the range 490.5 to $1197.52 \mathrm{~Bq} / \mathrm{m}^{3}$ with an average $732.78 \mathrm{~Bq} / \mathrm{m}^{3}$. The highest value was in AL-Dora refinery near white oil tanks and the lowest in AL-Karada region as shown in Figure 4.

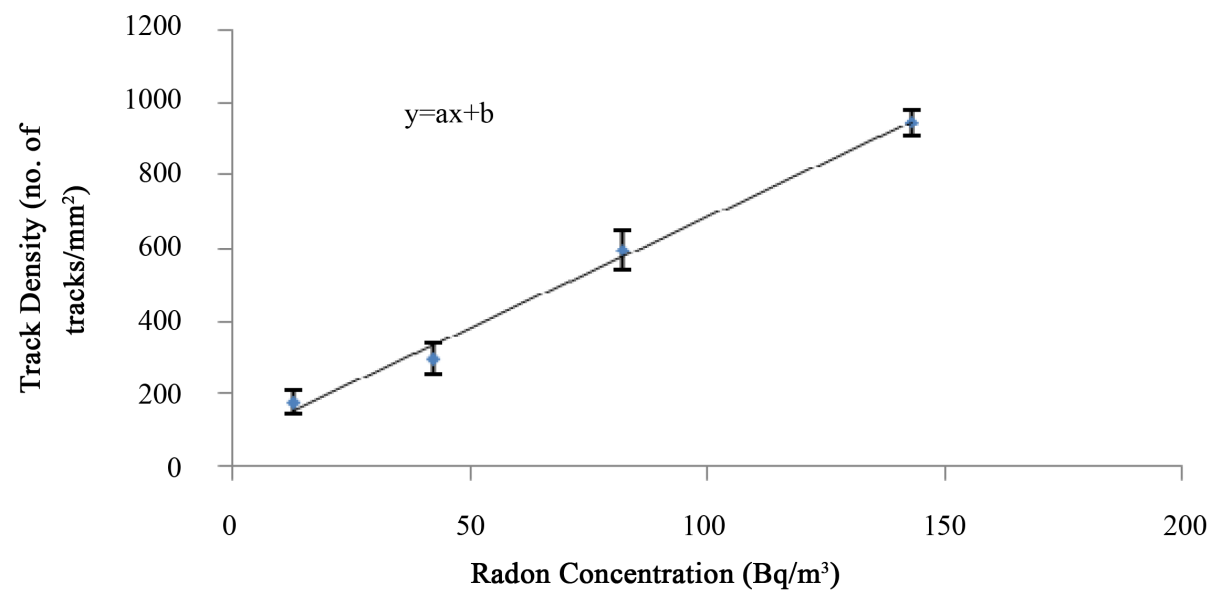

Figure 2. Radon concentration $\left(\mathrm{Bq} / \mathrm{m}^{3}\right)$ and track density for standard samples [9].

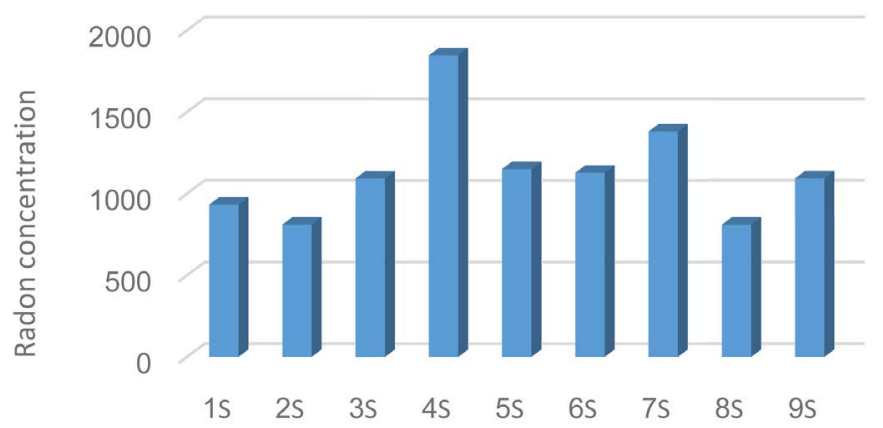

Figure 3. Radon concentrations for surface soil samples.

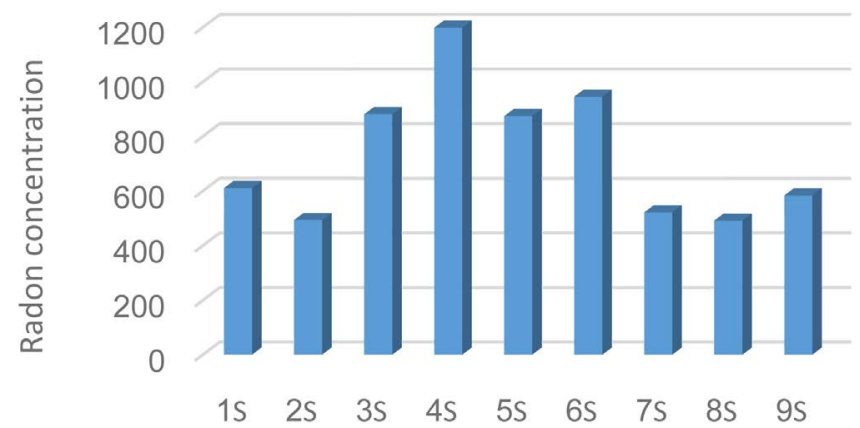

Figure 4. Radon concentrations for soil samples at depth $15 \mathrm{~cm}$. 


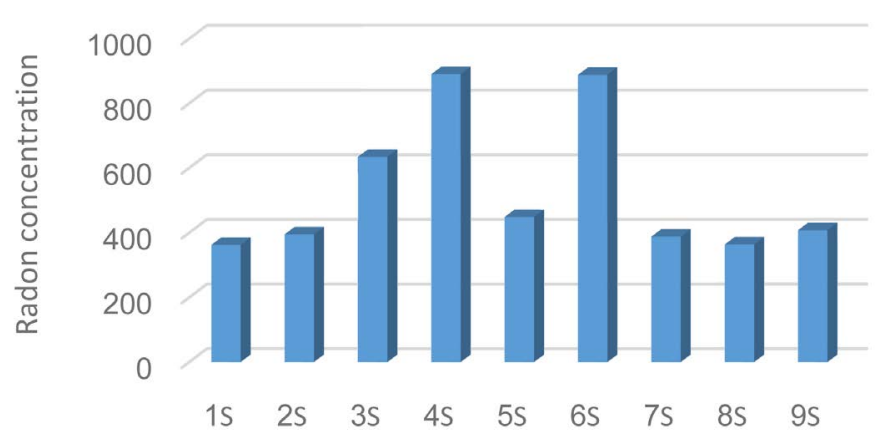

Figure 5. Radon concentrations for soil samples at the depth $30 \mathrm{~cm}$.

Table 2. Radon concentration, surface exhalation rate, mass exhalation rate for surface soils samples.

\begin{tabular}{cccc}
\hline Symbols & Radon Concentration $\mathrm{Bq} / \mathrm{m}^{3}$ & $E_{x}\left(\mathrm{~Bq} \cdot \mathrm{m}^{-2} \cdot \mathrm{h}^{-1}\right)$ & $E_{m}\left(\mathrm{~Bq} \cdot \mathrm{kg}^{-1} \cdot \mathrm{h}^{-1}\right)$ \\
\hline S1 & 932.66 & 0.5 & 0.11 \\
S2 & 810.08 & 0.44 & 0.09 \\
S3 & 1091.62 & 0.59 & 0.13 \\
S4 & 1845.6 & 0.99 & 0.21 \\
S5 & 1149.62 & 0.62 & 0.13 \\
S6 & 1127.08 & 0.61 & 0.13 \\
S7 & 1380.08 & 0.74 & 0.16 \\
S8 & 810.08 & 0.44 & 0.09 \\
S9 & 1091.85 & 0.59 & 0.13 \\
Average & 1137.71 & 0.61 & 0.131 \\
\hline
\end{tabular}

Table 3. Radon concentration, surface exhalation rate, mass exhalation rate for soils samples at depth $15 \mathrm{~cm}$.

\begin{tabular}{cccc}
\hline Symbols & Radon Concentration Bq/m & $E_{x}\left(\mathrm{~Bq} \cdot \mathrm{m}^{-2} \cdot \mathrm{h}^{-1}\right)$ & $E_{m}\left(\mathrm{~Bq} \cdot \mathrm{kg}^{-1} \cdot \mathrm{h}^{-1}\right)$ \\
\hline S1 & 610.03 & 0.33 & 0.07 \\
S2 & 493.1 & 0.27 & 0.057 \\
S3 & 880.53 & 0.47 & 0.10 \\
S4 & 1197.52 & 0.64 & 0.14 \\
S5 & 873.49 & 0.47 & 0.10 \\
S6 & 945.34 & 0.51 & 0.11 \\
S7 & 521.27 & 0.28 & 0.06 \\
S8 & 490.5 & 0.26 & 0.056 \\
S9 & 583.26 & 0.31 & 0.067 \\
Average & 732.78 & 0.39 & 0.084 \\
\hline
\end{tabular}

The radon concentration in soil from depth $30 \mathrm{~cm}$ ranged from 362.07 to $889.53 \mathrm{~Bq} / \mathrm{m}^{3}$ with an average $530.41 \mathrm{~Bq} / \mathrm{m}^{3}$, the highest concentration was in AL-Dora refinery near white oil tanks as shown in Figure 5.

The average of radon concentration for surface, 15 and $30 \mathrm{~cm}$ soil samples were 1137.71, 732.78 and 530.41 $\mathrm{Bq} / \mathrm{m}^{3}$ as shown in Figure 6.

The radon concentration in dust samples were at the range 281.77 to $1620.17 \mathrm{~Bq} / \mathrm{m}^{3}$ with an average 2496.3347 Bq/ $\mathrm{m}^{3}$ as shown in Table 5 and Figure 6. The surface exhalation rate were at the range 0.15 $\mathrm{Bq} \cdot \mathrm{m}^{-2} \cdot \mathrm{h}^{-1}$ to $2.16 \mathrm{~Bq} \cdot \mathrm{m}^{-2} \cdot \mathrm{h}^{-1}$ with average $1.34 \mathrm{~Bq} \cdot \mathrm{m}^{-2} \cdot \mathrm{h}^{-1}$. While the mass exhalation rate were at the range 
Table 4. Radon concentration, surface exhalation rate, mass exhalation rate for soils samples at depth $30 \mathrm{~cm}$.

\begin{tabular}{cccc}
\hline Symbols & Radon Concentration $\mathrm{Bq} / \mathrm{m}^{3}$ & $E_{x}\left(\mathrm{~Bq} \cdot \mathrm{m}^{-2} \cdot \mathrm{h}^{-1}\right)$ & $E_{m}\left(\mathrm{~Bq} \cdot \mathrm{kg}^{-1} \cdot \mathrm{h}^{-1}\right)$ \\
\hline S1 & 362.07 & 0.19 & 0.042 \\
S2 & 394.48 & 0.21 & 0.045 \\
S3 & 633.98 & 0.34 & 0.073 \\
S4 & 889.53 & 0.48 & 0.11 \\
S5 & 448.01 & 0.24 & 0.05 \\
S6 & 887.57 & 0.48 & 0.10 \\
S7 & 387.43 & 0.21 & 0.04 \\
S8 & 363.48 & 0.19 & 0.042 \\
S9 & 407.16 & 0.22 & 0.047 \\
Average & 530.41 & 0.28 & 0.06 \\
\hline
\end{tabular}

Table 5. Radon concentration, surface exhalation rate, mass exhalation rate in dust samples.

\begin{tabular}{|c|c|c|c|}
\hline Location & Radon Concentration $\mathrm{Bq} / \mathrm{m}^{3}$ & $E_{x}\left(\mathrm{~Bq} \cdot \mathrm{m}^{-2} \cdot \mathrm{h}^{-1}\right)$ & $E_{m}\left(\mathrm{~Bq} \cdot \mathrm{kg}^{-1} \cdot \mathrm{h}^{-1}\right)$ \\
\hline Dora dust & 1620.17 & 0.87 & 0.19 \\
\hline Karada dust & 4015.21 & 2.16 & 0.46 \\
\hline Zaafranjh dust & 281.77 & 0.15 & 0.032 \\
\hline new Baghdad dust & 3268.52 & 1.75 & 0.377 \\
\hline Dora refinery dust & 3296.7 & 1.77 & 0.38 \\
\hline average & 2496.3347 & 1.34 & 0.29 \\
\hline
\end{tabular}

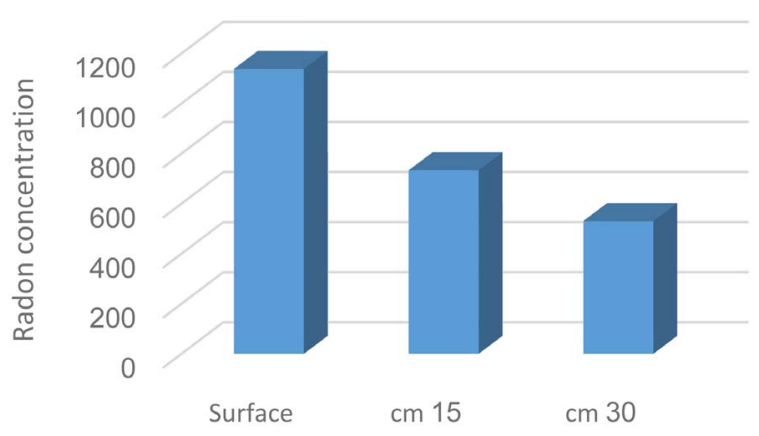

Figure 6. Average radon concentration at surface, $15 \mathrm{~cm}$ and $30 \mathrm{~cm}$ soil samples.

0.032 to $0.46 \mathrm{~Bq} \cdot \mathrm{kg}^{-1} \cdot \mathrm{h}^{-1}$ with an average $0.29 \mathrm{~Bq} \cdot \mathrm{kg}^{-1} \cdot \mathrm{h}^{-1}$ as shown in Table 5 and Figure 7.

The radon exhalation rate in term of area in surface soil ranged from 0.44 to $0.99 \mathrm{~Bq} \cdot \mathrm{m}^{-2} \cdot \mathrm{h}^{-1}$ with average $0.61 \mathrm{~Bq} \cdot \mathrm{m}^{-2} \cdot \mathrm{h}^{-1}$ as shown in Table 2 .

The radon exhalation rate in terms of area in soil samples at the depth $15 \mathrm{~cm}$ were at the range 0.22 to 0.64 $\mathrm{Bq} \cdot \mathrm{m}^{-2} \cdot \mathrm{h}^{-1}$ with average $0.39 \mathrm{~Bq} \cdot \mathrm{m}^{-2} \cdot \mathrm{h}^{-1}$.

The radon exhalation rate in terms of area in soil samples from depth $30 \mathrm{~cm}$ were at the range 0.19 to 0.48 $\mathrm{Bq} \cdot \mathrm{m}^{-2} \cdot \mathrm{h}^{-1}$ with average $0.28 \mathrm{~Bq} \cdot \mathrm{m}^{-2} \cdot \mathrm{h}^{-1}$. Figure 8 shows the average surface exhalation rate for surface, $15 \mathrm{~cm}$ and $30 \mathrm{~cm}$ in $\mathrm{Al}$ Dora soil samples.

Mass exhalation rate in surface soil were at the range 0.09 to $0.21 \mathrm{~Bq} \cdot \mathrm{kg}^{-1} \cdot \mathrm{h}^{-1}$ with average $0.12 \mathrm{~Bq} \cdot \mathrm{kg}^{-1} \cdot \mathrm{h}^{-1}$. Mass exhalation rate in soil samples from depth $15 \mathrm{~cm}$ were at the range 0.046 to $0.14 \mathrm{~Bq} \cdot \mathrm{kg}^{-1} \cdot \mathrm{h}^{-1}$ with average $0.08 \mathrm{~Bq} \cdot \mathrm{kg}^{-1} \cdot \mathrm{h}^{-1}$. Mass exhalation rate in soil samples from depth $30 \mathrm{~cm}$ were at the range 0.042 to 0.1 $\mathrm{Bq} \cdot \mathrm{kg}^{-1} \cdot \mathrm{h}^{-1}$ with average $0.06 \mathrm{~Bq} \cdot \mathrm{kg}^{-1} \cdot \mathrm{h}^{-1}$. Figure 9 shows the average mass exhalation rate for surface, $15 \mathrm{~cm}$ 


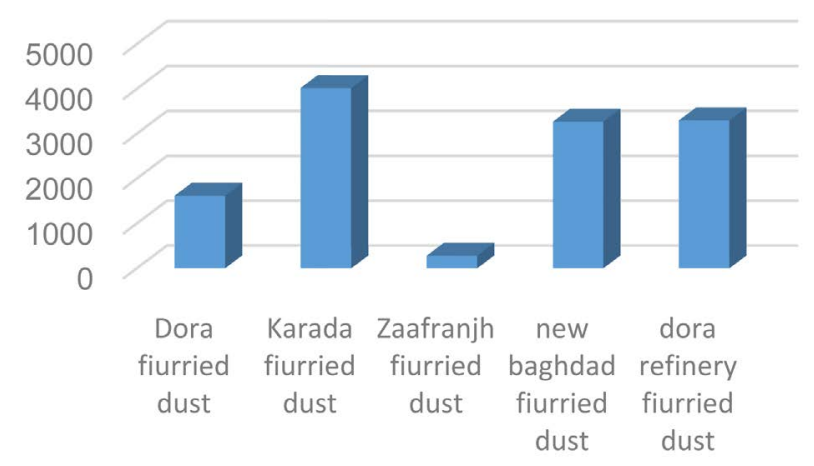

Figure 7. Radon concentration for dust samples.

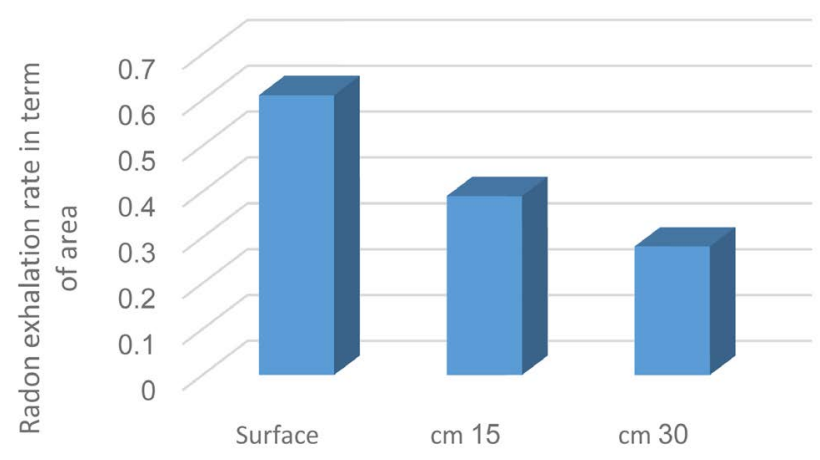

Figure 8. Average surface exhalation rate for surface, $15 \mathrm{~cm}$ and $30 \mathrm{~cm} \mathrm{Al} \mathrm{Dora} \mathrm{soil} \mathrm{samples.}$

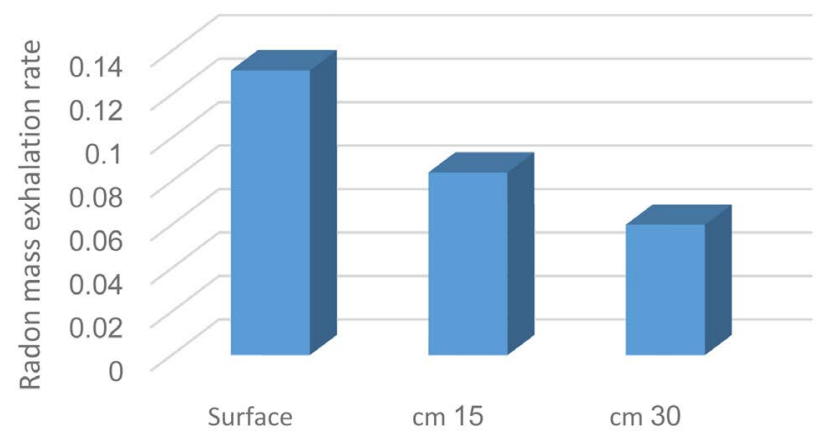

Figure 9. Average mass exhalation rate for surface, $15 \mathrm{~cm}$ and $30 \mathrm{~cm}$ in Al Dora soil samples.

and $30 \mathrm{~cm}$ in $\mathrm{Al}$ Dora soil samples.

It can be noticed that the highest radon concentration in soil samples from different depth were in AL-Dora refinery near white oil tanks which indicate that these region contaminated with natural occurring radioactive material-NORM comes from whit oil tanks.

The present results show that the radon concentration in soil samples (surface, $15 \mathrm{~cm}$ and $30 \mathrm{~cm}$ depth) and dust samples was higher than the global permissibility limit of exposure to radon inside building for the population $\left(200 \mathrm{~Bq} \cdot \mathrm{m}^{-3}\right)$ [12]. This concentrations comes from-NORM which are the main sources of radiation in soils and rocks.

\section{Conclusions}

The results of the present work provide an additional database on radon concentration in AL-Dora refinery soil samples (surface, $15 \mathrm{~cm}$ and $30 \mathrm{~cm}$ ) depth. 
The higher concentration in soil samples was found in AL-Dora refinery near white oil tanks at different depths.

The radon concentration in dust samples was found higher than the global permissibility limit of exposure to radon inside buildings for the population $\left(200 \mathrm{~Bq} \cdot \mathrm{m}^{-3}\right)$. The reason of this concentration comes from the chimney of AL-Dora refinery which release this dust.

The average radon concentration in surface soil samples was found higher than the radon concentrations in soil from depth $15 \mathrm{~cm}$ and $30 \mathrm{~cm}$.

The average radon exhalation rate in terms of area and mass in the surface soil samples was higher than radon exhalation rate in terms of area and mass in soil samples from depth $15 \mathrm{~cm}$ and $30 \mathrm{~cm}$.

\section{Acknowledgements}

The authors are very grateful for Prof. Laith A. Najam from University of Mosul for reading the manuscript and for fruitful discussions.

\section{References}

[1] UNSCEAR Annex A (1988) Sources and Effects of Ionizing Radiation. United Nations Scientific Committee on the Effect of Atomic Radiation, United Nations, New York.

[2] Kurnaz, A., Küçükömeroğlu, B., Cevik, U. and Celebi, N. (2011) Radon Levels and Indoor Gamma Doses in Dwellings of Trabzon, Turkey. Applied Radiation and Isotopes, 69, 1554-1559. http://dx.doi.org/10.1016/j.apradiso.2011.06.016

[3] U.S. Environmental Protection Agency (2012) A Citizens Guide to Radon: The Guide to Protecting Yourself and Your Family from Radon; EPA 402/K-12/002, May 2012. www.epa.gov/radon

[4] UNSCEAR (1993) Sources and Effects of Ionizing Radiation. United Nations Scientific Committee on the Effects of Atomic Radiation, New York.

[5] Ai, N., Khan, E.U., Akhter, P., Khan, F. and Waheed, A. (2010) Estimation of Mean annual Effective Dose through Radon Concentration in the Water and Indoor air of Islamabad and Murree. Radiation Protection Dosimetry, 141, 183-191. http://dx.doi.org/10.1093/rpd/ncq160

[6] Ramola, R.C., Choubey, V.M., Negi, M.S., Prasad, Y. and Prasad, G. (2008) Radon Occurrence in Soil Gas and Groundwater around an Active Landslide. Radiation Measurements, 43, 98-101. http://dx.doi.org/10.1016/j.radmeas.2007.05.054

[7] Rebelo, A.M., Bittencourt, A.V. and Mantovani, L.E. (2009) Modelos de Exalação de Radônioem Paisagens Tropicais Úmidassobre Granito. BoletimParanaense de Geociências, Paraná, 52, 61-76.

[8] Shweikani, R. and Raja, G. (2009) Radon Exhalation from Some Finishing Materials Frequently Used in Syria. Radiation Measurement, 44, 1019-1023. http://dx.doi.org/10.1016/j.radmeas.2009.10.034

[9] Najam, L.A., Tawfiq, N.F. and Mahmood, R.H. (2013) Radon Concentration in Some Building Materials in Iraq Using CR-39 Track Detector. International Journal of Physics, 1, 73-76.

[10] Faheem, M. and Matiullah (2008) Radon Exhalation and Its Dependence on Moisture Content from Samples of Soil and Building Materials. Radiation Measurement, 43, 1458-1462. http://dx.doi.org/10.1016/j.radmeas.2008.02.023

[11] Ramola, R.C. and Choubey, V.M. (2003) Measurement of Radon Exhalation Rate from Soil Samples of Garhwal Himalaya, India. Journal of Radioanal and Nuclear Chemistry, 256, 219-223. http://dx.doi.org/10.1023/A:1023920930746

[12] ICRP (1993) “Protection against Radon-222 at Home and Work” ICRP Publication 65. Pergamon Press, Oxford. 